\title{
SIMILARITIES AND DIFFERENCES BETWEEN THE CHAETOPTERUS VARIOPEDATUS POLYCHAETE LUCIFERASES DEPENDING ON THE TYPE OF HABITAT
}

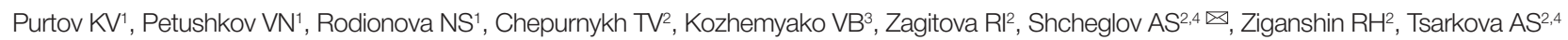

${ }^{1}$ Institute of Biophysics, Krasnoyarsk Science Center of the Siberian Branch of the Russian Academy of Sciences, Russia

2 Shemyakin-Ovchinnikov Institute of Bioorganic Chemistry, Moscow, Russia

${ }^{3}$ Pacific State Medical University, Vladivostok, Russia

${ }^{4}$ Pirogov Russian National Research Medical University, Moscow, Russia

The marine polychaete Chaetopterus variopedatus (Renier) (family Chaetopteridae) is a cosmopolitan species complex, consisting of distinct populations/ subspecies. The worms release glowing $(460 \mathrm{~nm})$ clouds of mucus when disturbed, and their parapodia often glow brightly. Currently, it is still unclear how exactly the bioluminescence system of these polychaetes functions. It has been previously assumed that the $C$. variopedatus luciferase may be used for detection of ferroptosis, the recently explored pathway of programmed cell death, resulting from accumulation of the ferrous ions. This study was aimed to extract and characterize the C. variopedatus luciferases, as well as to compare luciferases obtained from $C$. variopedatus of different populations. When extracting the enzyme responsible for bioluminescence from the frozen samples of Brazilian C. variopedatus using the improved method, two active luciferases, L1 and L2, were obtained. We assumed that one of the listed above luciferases was responsible for luminescence of the mucus and the other luciferase was responsible for luminescence in parapodia, and used the method for the distinct samples of mucus and parapodia of the living Far Eastern C. variopedatus. However, mucus of the latter turned out to be non-glowing. It is shown that luciferase L2 is responsible for luminescence in the parapodia of the $C$. variopedatus polychaete, since this luciferase has been found in the total biomass of Brazilian polychaetes and parapodia of Far Eastern polychaetes. Luminescence of the Brazilian $C$. variopedatus mucus is attributed to the functioning of luciferase L1, which is lacking in the mucus of the Far Eastern subspecies. The range of luciferase isoforms in polychaetes $C$. variopedatus depends on the place of origin.

Keywords: bioluminescence, luciferase, polychaetes, Chaetopterus variopedatus, marine worms

Acknowlegements: we would like to thank Anderson Oliveira, Professor, and Jeremy Mirza, junior researcher at the Oceanographic Institute of the University of São Paulo for assistance in collecting the biomass of Brazilian polychaetes, and Kirill Vinnikov, Director at the Institute of Marine Biology, Far Eastern Federal University, for advice on the Chaetopterus taxonomy.

Author contribution: Purtov KV, Petushkov VN, Rodionova NS - luciferase extraction; Chepurnykh TV - DNA extraction, PCR; Kozhemyako VB - biomass collection and preparation for luciferase extraction; Zagitova RI, Shcheglov AS - studying the properties of luciferases; Ziganshin RH - mass spectrometry; Tsarkova AS — overall project management.

$\triangle$ Correspondence should be addressed: Aleksandr S. Shcheglov Miklukho-Maklaya, 16/10, Moscow, 117997, Russia; jukart@mail.ru

Received: 28.09.2021 Accepted: 12.10.2021 Published online: 26.10.2021

DOI: 10.24075/brsmu.2021.049

\section{СХОДСТВО И РАЗЛИЧИЯ ЛЮЦИФЕРАЗ ПОЛИХЕТ СНАETOPTERUS VARIOPEDATUS В ЗАВИСИМОСТИ ОТ МЕСТА ИХ ОБИТАНИЯ}

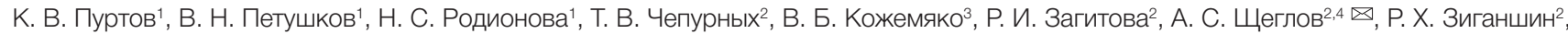
А. С. Царькова

${ }^{1}$ Институт биофизики, Красноярский научный центр Сибирского отделения Российской Академии наук, Россия

2 Институт биоорганической химии имени академиков М. М. Шемякина и Ю. А. Овчинникова, Москва, Россия

${ }^{3}$ Тихоокеанский государственный медицинский университет, Владивосток, Россия

${ }^{4}$ Российский национальный исследовательский медицинский университет имени Н. И. Пирогова, Москва, Россия

Морские полихеты Chaetopterus variopedatus (Renier) (семейство Chaetopteridae) - космополиты, представляющие собой видовой комплекс из отдельных популяций-подвидов. При раздражении черви выпускают светящиеся (460 нм) облака слизи, при этом часто ярко светятся и их параподии. На сегодняшний день по-прежнему не ясно, как именно работает биолюминесцентная система этих полихет. Ранее было выдвинуто предположение, что люцисераза C. variopedatus может быть использована для детекции ферроптоза - недавно открытого пути программируемой клеточной гибели, вызванной накоплением ионов двухвалентного железа. Целью исследования было выделить и охарактеризовать люциферазы С. variopedatus, а также сравнить люциферазы C. variopedatus из разных популяций. При выделении ответственного за биолюминесценцию фермента из замороженных образцов бразильских C. variopedatus по усовершенствованной методике были получены две активные люциферазы - L1 и L2. Предположив, что одна из указанных люцифераз определяет свечение слизи, а другая - свечение параподий червей, эту же методику применили к раздельным образцам слизи и параподий живых дальневосточных C. variopedatus. Однако их слизь оказалась несветящейся. Показано, что функцию свечения параподий полихет C. variopedatus обеспечивает люцифераза L2, так как она обнаружена в общей биомассе бразильских полихет и в параподиях дальневосточных полихет. Свечение слизи бразильских C. variopedatus обусловлено функционированием люциферазы L1, которая отсутствует в слизи дальневосточного подвида. Набор изоформ люцифераз полихет C. variopedatus зависит от места их обитания.

Ключевые слова: биолюминесценция, люцифераза, полихеты, Chaetopterus variopedatus, морские черви

Благодарности: просессору Андерсону Оливейра и младшему научному сотруднику Джереми Мирза (Океанограсический институт Университета Сан-Паулу) за помощь в сборе биомассы бразильских полихет, а также директору Института Мирового океана Дальневосточного федерального университета Кириллу Винникову за консультации по вопросам систематики Chaetopterus.

Вклад авторов: К. В. Пуртов, В. Н. Петушков, Н. С. Родионова - выделение люциферазы; Т. В. Чепурных - выделение ДНК, проведение ПЦР; В. Б. Кожемяко - сбор и подготовка биомассы для выделения люциферазы; Р. И. Загитова, А. С. Щеглов - исследование свойств люцифераз; Р. Х. Зиганшин - масс-спектрометрический анализ; А. С. Царькова - общее руководство проектом.

$\triangle$ Для корреспонденции: Александр Сергеевич Щеглов ул. Миклухо-Маклая, д. 16/10, г. Москва, 117997, Россия; jukart@mail.ru

Статья получена: 28.09.2021 Статья принята к печати: 12.10.2021 Опубликована онлайн: 26.10.2021

DOI: $10.24075 /$ vrgmu.2021.049 
Chaetopterus variopedatus (Renier) belongs to the family Chaetopteridae, one of the most differentiated family of marine polychaetes inhabiting the benthic sediments during the adult stage, except for the uncommon pelagic species C. pugaporcinus (Osborn) [1]. Various researchers describe C. variopedatus as a species complex consisting of distinct populations/subspecies [2-4]. C. variopedatus is a cosmopolitan species living in temperate and tropical regions across the world. Various $C$. variopedatus subspecies are found in the coastal zones in Russia, Japan, Australia, Brazil, Europe and the USA [5]. A few years ago, phylogenetic relationships within Chaetopteridae were revised $[1,6]$, however, there remains considerable uncertainty about C. variopedatus sensu lato (Hartman).

C. variopedatus lives, hiding in the self-constructed $U$-shaped parchment-like tube, which is buried in the substrate. It has a segmented body with paired appendages, termed parapodia. C. variopedatus releases the blue-glowing $\left(\lambda_{\max } 460 \mathrm{~nm}\right)$ clouds of mucus in response to aggressive external stimuli [7]. Concurrently, parapodia of all body segments also glow brightly. This phenomenon historically attracted the attention of curious observers, which is confirmed by numerous reports. Many researchers have tried to understand the biochemical aspects of the C. variopedatus luminescence over the past 70 years [8-10]. However, the results are still controversial. To date, it is yet unclear how exactly the bioluminescence system of these polychaetes functions.

As previously reported, preparation of luciferase, which was used to reproduce the characteristic bioluminescence reaction in vitro, was obtained from the C. variopedatus biomass, collected in the São Sebastião Strait off the coast of Brazil. In order to achieve in vitro bioluminescence, the alcoholic extract of $C$. variopedatus, containing the main substrate (luciferin) and the ferrous ions, was added to the preparation of luciferase [11].

We have suggested that the C. variopedatus luciferase may be used to detect ferroptosis [12], the recently discovered pathway of programmed cell death, resulting from accumulation of the ferrous ions [13]. Ferroptosis investigations are important for both fundamental and applied biomedical science. It has been shown that the processes similar to ferroptosis occur in some neurodegenerative diseases [14]. Moreover, ferroptosis inductors have a high potential as anticancer drugs [15].

Thus, detailed characterization and decoding of the C. variopedatus bioluminescence system is considered an urgent scientific challenge. This study was aimed at the extraction and characterization of $C$. variopedatus luciferases, and at comparative examination of luciferases, obtained from C. variopedatus of different populations.

\section{METHODS}

\section{Collection of $C$. variopedatus biomass}

C. variopedatus was collected at two locations: São Sebastião Strait of the coast of Brazil and Trinity bay in the Possiet Gulf of Japan Sea. The worms were pulled out of their tubes and immediately frozen in liquid nitrogen. The frozen polychaetes were shipped on dry ice and stored at $-70^{\circ} \mathrm{C}$.

In order to obtain the glowing mucus, the worms were pulled out of the tubes, placed in the seawater and subjected to mechanical stimulation in the dark. The glowing mucus was collected with a pipette and frozen in liquid nitrogen.

\section{Luciferase extraction}

A total of $100 \mathrm{~g}$ of the frozen C. variopedatus biomass were homogenized in $900 \mathrm{~mL}$ of $50 \mathrm{mM}$ Tris buffer, $\mathrm{pH}$ 7.5. The homogenate was sonicated using Ultrasonic Disintegrator UD-20 (Techpan; Poland) 5 times for 2 min on ice and subsequently centrifuged (25 $000 \mathrm{~g} \times 20 \mathrm{~min}$ ) at $4^{\circ} \mathrm{C}$. Supernatant was supplemented with ammonium sulfate to the final concentration of $500 \mathrm{mM}$ and passed through a cellulose DEAE column (Cellulose DEAE-32, Serva; Germany), equilibrated with 500 $\mathrm{mM}$ ammonium sulfate. The resulting filtrate was loaded onto the $25 \times 100 \mathrm{~mm}$ Phenyl Sepharose CL-4B column (Cytiva; USA), equilibrated with $500 \mathrm{mM}$ ammonium sulfate. Luciferase was eluted with $5 \mathrm{mM}$ Tris-HCl buffer, $\mathrm{pH}$ 7.5.

Fractions, possessing luciferase activity, were combined and loaded onto the $16 \times 200 \mathrm{~mm}$ Sepharose DEAE FF column (Cytiva; USA), equilibrated with $20 \mathrm{mM}$ Tris- $\mathrm{HCl}, \mathrm{pH}$ 7.5; the column was washed with the same buffer, and the linear gradient elution was performed. Buffer A: $20 \mathrm{mM}$ Tris- $\mathrm{HCl}$, $\mathrm{pH}$ 7.5; buffer B: $500 \mathrm{mM} \mathrm{NaCl}, 20 \mathrm{mM}$ Tris-HCl, $\mathrm{pH}$ 7.5. The flow rate was $4 \mathrm{~mL} / \mathrm{min}$, and the time of gradient was $25 \mathrm{~min}$.

The resulting preparation was concentrated on the $10 \mathrm{kDa}$ cell (Amicon; Ireland) and loaded onto the $26 \times 400 \mathrm{~mm}$ Sephacryl S200 column (Cytiva; USA), equilibrated with $200 \mathrm{mM} \mathrm{NaCl}$ and $20 \mathrm{mM}$ Tris-HCl, $\mathrm{pH}$ 7.5. Elution was performed with the same buffer at a rate of $1.5 \mathrm{~mL} / \mathrm{min}$. The pooled fractions possessing luciferase activity were supplemented with ammonium sulfate to the final concentration of $500 \mathrm{mM}$, the resulting solution was loaded onto the $5 \times 90 \mathrm{~mm}$ C8 column (Cytiva; USA). The linear gradient elution was carried out. Buffer A: 500 mM ammonium sulfate, $5 \mathrm{mM}$ Tris- $\mathrm{HCl}$, $\mathrm{pH}$ 7,5; buffer $\mathrm{B}$ : $5 \mathrm{mM}$ Tris- $\mathrm{HCl}$, $\mathrm{pH}$ 7.5. The flow rate was $0.5 \mathrm{~mL} / \mathrm{min}$, and the time of gradient was $80 \mathrm{~min}$.

The resulting luciferase preparation was diluted twice with distilled water and loaded onto the $3 \times 50 \mathrm{~mm}$ monoQ column (Cytiva; USA), equilibrated with $20 \mathrm{mM}$ Tris- $\mathrm{HCl}, \mathrm{pH}$ 7.5; the column was washed with the same buffer, and the linear gradient elution was performed. Buffer A: $20 \mathrm{mM}$ Tris- $\mathrm{HCl}, \mathrm{pH}$ 7.5; buffer B: $500 \mathrm{mM} \mathrm{NaCl}, 20 \mathrm{mM}$ Tris- $\mathrm{HCl}, \mathrm{pH}$ 7.5. The flow rate was $0.5 \mathrm{~mL} / \mathrm{min}$, and the time of gradient was $80 \mathrm{~min}$.

The preparation was concentrated to a volume of $200 \mu \mathrm{L}$ on the $10 \mathrm{kDa}$ centrifuge filter (Amicon; Ireland) with subsequent gel filtration through the $10 \times 300 \mathrm{~mm}$ Superdex 200 column (Cytiva; USA), equilibrated with $100 \mathrm{mM} \mathrm{NaCl}, 50 \mathrm{mM}$ Tris- $\mathrm{HCl}$, $\mathrm{pH}$ 7.5. Elution was performed with the same buffer at a rate of $0.8 \mathrm{~mL} / \mathrm{min}$.

Luciferase was extracted from the glowing mucus $(10 \mathrm{~mL})$ by the same method. Luciferase activity was measured in accordance with the previously developed protocol [11].

The species specificity of the available Chaetopterus specimens was defined using the following primers: HC02198 (5'-TAAACTTCAGGGTGACCAAAAAATCA-3') and LCO1490 (5'-TCAACAAATCATAAAGATATTGG-3'). DNA was extracted from each $C$. variopedatus frozen tissue sample with the use of the ExtractDNA Blood \& Cells kit (Evrogen; Russia). After that the $\mathrm{COI}$ gene fragment sequences with a length of 650 bps were amplified using the listed above primers, and DNA extracted from each frozen tissue specimen was used as a template. PCR products were used for Sanger sequencing.

Mass spectrometry analysis of purified luciferase preparations, obtained from Brazilian and Far Eastern C. variopedatus, was carried out using the $Q$ Exactive Plus mass spectrometer (Thermo Fisher Scientific; USA) coupled with the Ultimate 3000 Nano LC System (Thermo Fisher Scientific; USA) by means of the nanoelectrospray ionization source (Thermo Fisher Scientific; USA). Full scan MS acquisition was carried out with the following parameters: 140k resolution, normal mass range (500-2000 amu), AGC target $3^{\star} 10^{6}$, max. injection time 


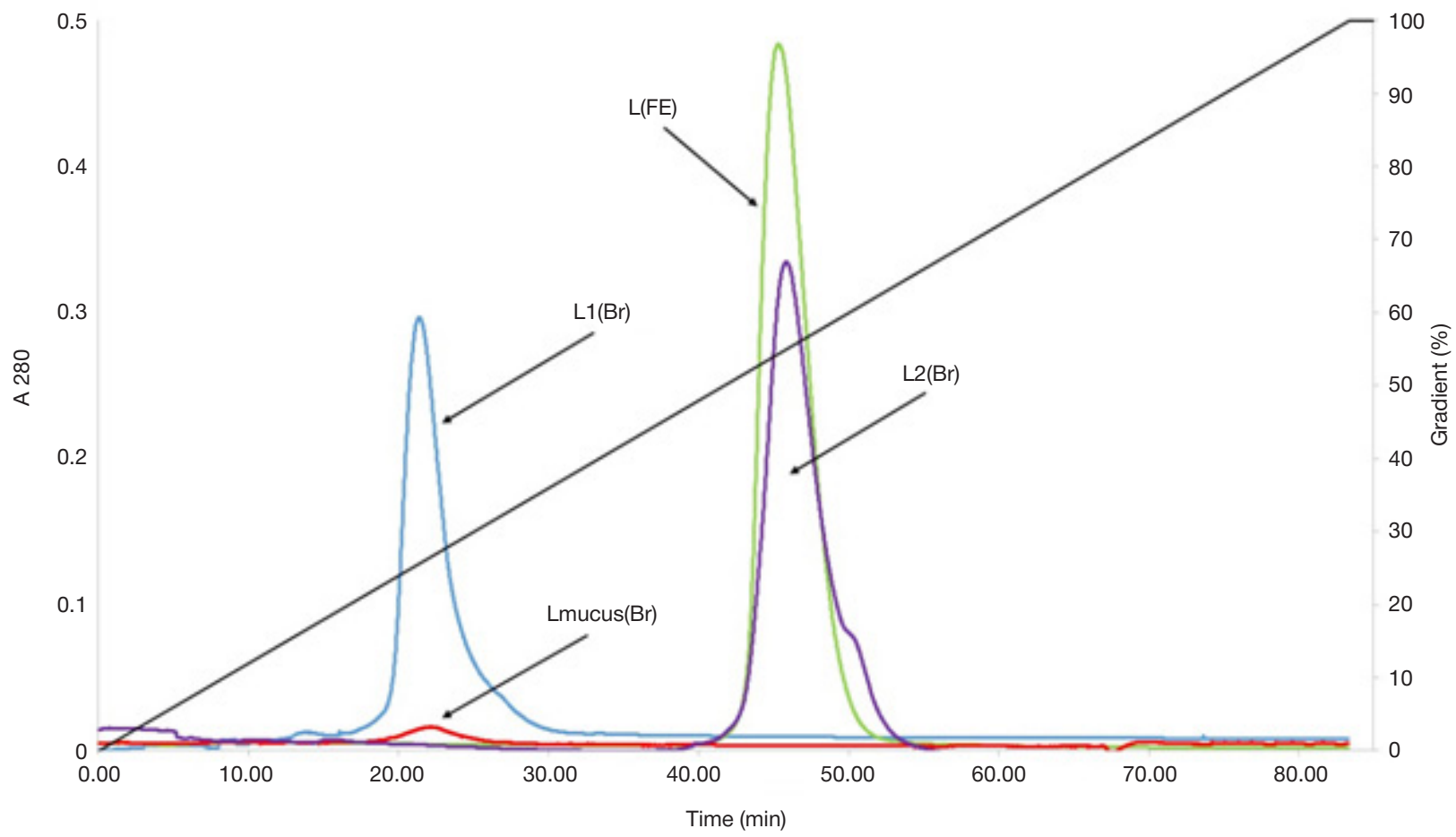

Fig. 1. Retention time values obtained for different $C$. variopedatus luciferases by chromatography involving the use of the monoQ anion exchange column, linear gradient; $\mathrm{Br}$ - Brazilian polychaetes, FE — Far Eastern polychaetes

$30 \mathrm{~ms}$. The raw data obtained were visualized with the XCalibur software (Thermo Fisher Scientific; USA).

\section{RESULTS}

The use of high-resolution anion exchange chromatography resulted in the target preparation separated into two almost homogeneous luciferases: L1, retention time $21.5 \mathrm{~min}$, and L2, retention time $46 \mathrm{~min}$ (Fig. 1). The native molecular weight of those, calculated based on the results of gel filtration, was $70 \mathrm{kDa}$ and $60 \mathrm{kDa}$, respectively (Fig. 2).

Under denaturing conditions of SDS electrophoresis, luciferase L1 consisted of two mono subunits, each about $18 \mathrm{kDa}$, and L2 consisted of at least two different subunits with a mass of about 18 and $15 \mathrm{kDa}$ (Fig. 3).

The existence of two different luciferases in one animal may be indicative either of their differing origins or of their specific functions $[16,17]$. Although the $C$. variopedatus luminescence is monochrome (blue), each of the worm's luciferases probably functions locally: for example, one could be responsible for parapodia luminescence, and the other could be responsible for luminescence of mucus, released by the worm into the external environment.

To test this hypothesis, we used the sample of mucus, collected and frozen separately when catching Brazilian C. variopedatus. Chromatographic analysis of the preparation, purified in accordance with the described above method, revealed the presence of one luciferase only, and the retention time on the monoQ column (45.5 min) for this luciferase showed reasonable agreement with the retention time measured for L1, previously extracted from the total worm biomass (see Fig. 1). No specific samples of the Brazilian polychaetes were available, and the amount of the obtained L1 and L2 turned out to be insufficient for sequencing. That is why the authors

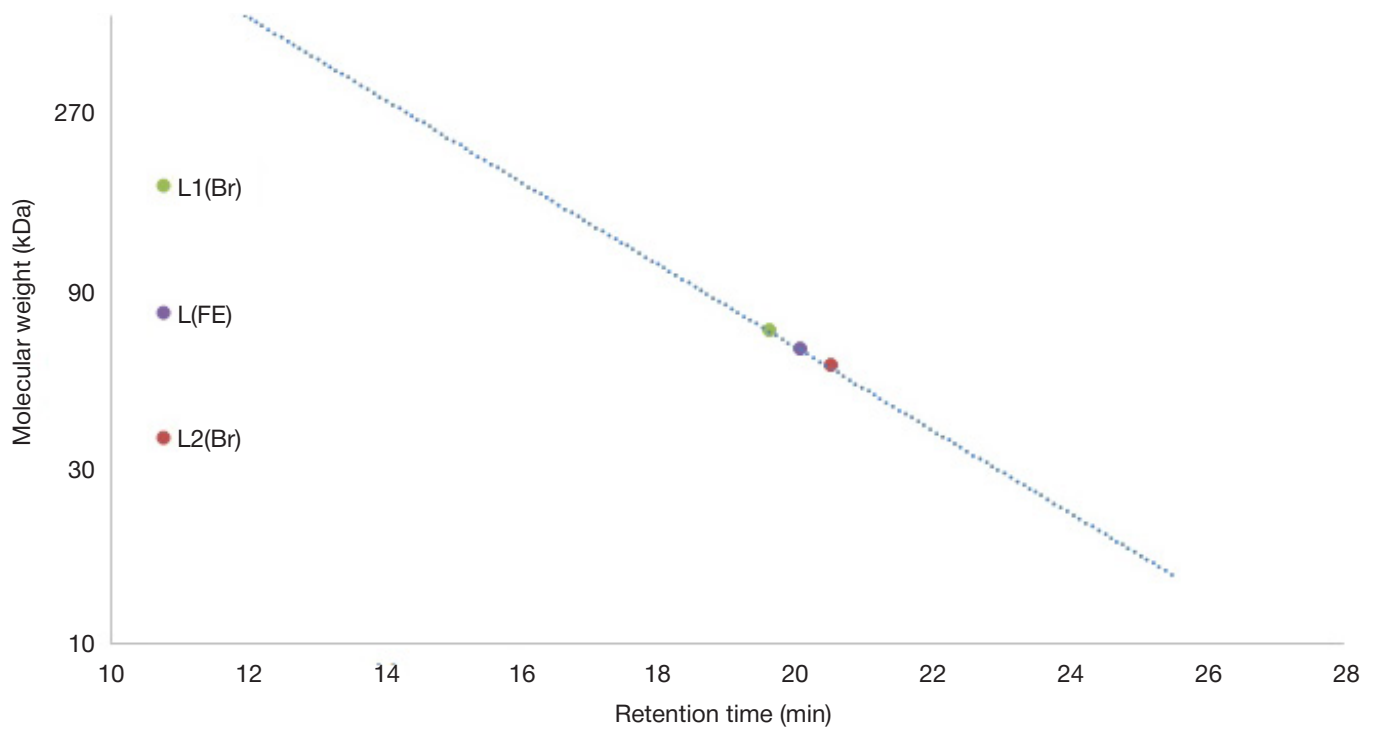

Fig. 2. Molecular weight of different $C$. variopedatus luciferases defined by gel filtration; $\mathrm{Br}$ - Brazilian polychaetes, FE — Far Eastern polychaetes 


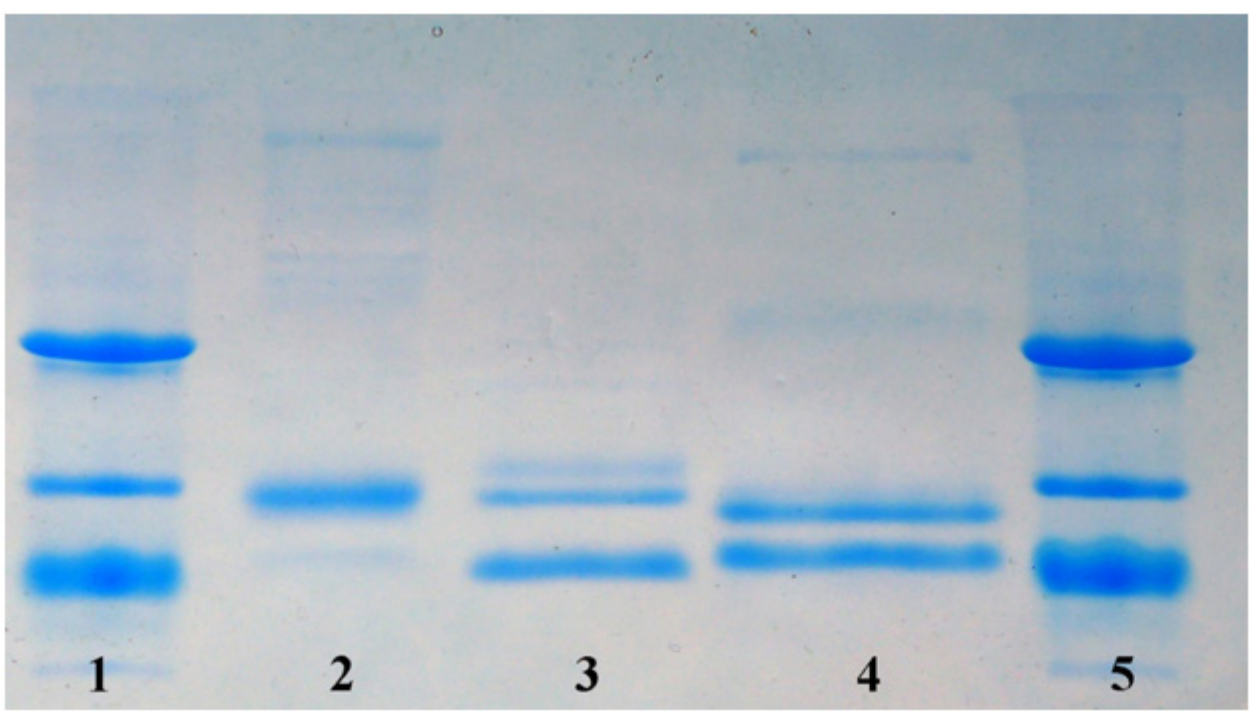

Fig. 3. Denaturing electrophoresis (15\% SDS-PAGE) of the preparations L1 (2) and L2 (3) obtained from Brazilian C. variopedatus and luciferase obtained from Far Eastern C. variopedatus (4). Tracks 1 and 5 - protein calibration mixture for SDS-PAGE electrophoresis: 29,000, 21,000, 12,500, 6,500 kDa

turned to the closer source of these worms, the Far East coast of Russia.

Polychaetes, collected in the Trinity bay in the Gulf of Possiet of Japan Sea, were initially identified as $C$. variopedatus based on morphological features and delivered to the laboratory alive. In order to better define the species specificity of the available Chaetopterus, the authors performed sequencing of the $650 \mathrm{bp}$ fragment of the cytochrome $\mathrm{C}$ oxidase subunit gene (COI). Sequence analysis using the GenBank database showed that the $\mathrm{COI}$ fragments of Brazilian and Far Eastern samples were higly gomologous (over 99\%) to those of two different subspecies: C. variopedatus (AM503096.1) and C. cautus Marenzeller (LC533809.1), respectively. To date, these subspecies have been merged into one species complex, C. variopedatus [6].

When collecting the Far Eastern polychaetes, their mucus was frozen separately. We failed to detect luminescence after defrosting the mucus at the laboratory. The portions of fresh mucus, obtained by mechanical and chemical stimulation of living worms, did not glow as well. Adding luciferin and ferrous iron to the mucus samples also did not lead to light emission. The efforts to extract luciferase from the mucus samples in accordance with the described above method were unsuccessful.

No problems with the detection of the Far Eastern polychaete parapodia luminescence were encountered. From those we managed to extract a highly purified luciferase L(FE) with a native molecular weight of $65 \mathrm{kDa}$ (see Fig. 2). The retention time on the monoQ column for this luciferase was $45.5 \mathrm{~min}$, which was almost equal with the retention time of the luciferase L2 (see Fig. 1). Denaturing SDS electrophoresis demonstrates that both $L(F E)$ and $L 2$ of Brazilian polychaetes consist of two different subunits. These subunits' molecular masses are also almost similar (see Fig. 3).

We performed mass spectrometry analysis of the preparations of purified luciferases, obtained from Brazilian and Far Eastern Chaetopterus. The results, mass-to-charge ratio $(\mathrm{m} / \mathrm{z})$, charge $(\mathrm{z})$ and calculated molecular weight $(\mathrm{m})$, are presented in the Table.

Preparations of luciferases $L 2(\mathrm{Br})$ and $L(F E)$ are significantly more heterogenous compared to the $\mathrm{L} 1(\mathrm{Br})$ preparation, which is probably due to posttranslational modifications and terminal amino acid cleavage. Mass sets, obtained for $L 2(\mathrm{Br})$ and $L(F E)$, are almost the same, which attests to the enzymes similarity, and differ significantly from those obtained for $L 1(\mathrm{Br})$.

\section{DISCUSSION}

Bioluminescence systems are widely implemented in various biomedical technologies [18, 19]. Luminescence bioimaging, the intravital imaging of cells and intracellular processes, is one of the important areas [20]. In case of successful decoding, the $C$. variopedatus luciferase may conceivably be used for development of ferroptosis sensor [12]. We have optimized the

Table. Mass spectrometry analysis of the preparations of purified luciferases, obtained from Brazilian (Br) and Far Eastern (FE) Chaetopterus

\begin{tabular}{|c|c|c|c|c|c|c|c|c|}
\hline \multicolumn{3}{|c|}{$\mathrm{L} 1(\mathrm{Br})$} & \multicolumn{3}{|c|}{$\mathrm{L} 2(\mathrm{Br})$} & \multicolumn{3}{|c|}{$\mathrm{L}(\mathrm{FE})$} \\
\hline$m / z$ & $z$ & $m$ & $m / z$ & $z$ & $m$ & $m / z$ & $z$ & $m$ \\
\hline 1355.5 & 12 & 16253 & 1352.49 & 11 & 14866.39 & 1352.67 & 11 & 14868.37 \\
\hline 1364 & 12 & 16356 & 1364.5 & 11 & 14998.5 & 1355.5 & 12 & 16254 \\
\hline 1374.94 & 11 & 15113.34 & 1365.94 & 11 & 15014.34 & 1364.09 & 12 & 16357 \\
\hline \multirow[t]{6}{*}{1383.58} & 11 & 15208.38 & 1373.31 & 11 & 15095.41 & 1366.13 & 11 & 15016.43 \\
\hline & & & 1374.77 & 11 & 15111.47 & 1373.41 & 11 & 15096.51 \\
\hline & & & 1383.76 & 11 & 15210.36 & 1374.95 & 11 & 15113.45 \\
\hline & & & 1396.93 & 12 & 16751.16 & 1383.85 & 11 & 15211.35 \\
\hline & & & 1405.35 & 12 & 16852.2 & 1396.94 & 12 & 16751.28 \\
\hline & & & & & & 1404.44 & 12 & 16853.28 \\
\hline
\end{tabular}

Note: $m / z$ — mass-to-charge ratio; $z$ — charge; $m$ - molecular weight. 
previously developed method for the $C$. variopedatus luciferase extraction [11], thereby obtaining an almost pure preparation, suitable for mass spectrometry analysis.

Originally, C. variopedatus caught in Brazil were used for analysis, however, logistical challenges forced us to use C. variopedatus caught in Primorsky Krai in Russia. It is interesting that unlike Brazilian polychaetes, Far Eastern C. variopedatus did not produce any glowing mucus. Two different isoforms of luciferase (L1 and L2) were found in Brazilian C. variopedatus, while only one $(L)$ was found in Far Eastern polychaetes. Mass spectrometry and chromatography showed that $L 2$ and $L$ were extremely likely and differed from L1. Presumably, the function of parapodia luminescence in C. variopedatus polychaetes is ensured by luciferase $L 2(L)$, since this luciferase has been found in the total biomass of Brazilian polychaetes and parapodia of Far Eastern polychaetes.
Luminescence of mucus in Brazilian C. variopedatus is due to the functioning of luciferase $L 1$, which is lacking in the mucus of the Far Eastern subspecies.

\section{CONCLUSIONS}

The findings lead to the following conclusions: 1. the C. variopedatus polychaete parapodia luminescence is attributed to the function of luciferase $L 2$, since this luciferase has been identified in the total biomass of Brazilian polychaetes as L2(Br) and in parapodia of Far Eastern polychaetes as L(FE) identical to L2(Br); 2. the Brazilian C. variopedatus mucus luminescence is ensured by luciferase $L 1$, which is lacking in the mucus of the Far Eastern subspecies; 3. the range of luciferase isoforms in C. variopedatus polychaetes might correlate with their place of origin.

\section{References}

1. Osborn KJ, Rouse GW, Goffredi SK, Robison BH. Description and relationships of Chaetopterus pugaporcinus, an unusual pelagic polychaete (Annelida, Chaetopteridae). Biol Bull. 2007 212 (1): 40-54. DOI: 10.2307/25066579.

2. Petersen ME. Chaetopterus variopedatus (Renier) (Annelida: Polychaeta: Chaetopteridae): a species complex. What species are being used at MBL? Biol Bull. 1984; 167: 513

3. Petersen ME. Contribution to a revision of Chaetopterus Cuvier (Polychaeta: Chaetopteridae): redescription of C. appendiculatus Grube and C. cautus Marenzeller, with comments on some other species. Bull Mar Sci. 1997; 60: 619.

4. Bhaud M. The spreading potential of polychaete larvae does not predict adult distributions; consequences for conditions of recruitment. Hydrobiologia. 1998; 375: 35. DOI: 10.1023/A:1017073409259.

5. Mirza JD, Migotto AE, Yampolsky IV, de Moraes GV, Tsarkova AS, Oliveira AG. Chaetopterus variopedatus bioluminescence: review of light emission within a species complex. Photochem Photobiol. 2020; 96: 768-78. DOl: 10.1111/php.13221.

6. Moore JM, Nishi E, Rouse GW. Phylogenetic analyses of Chaetopteridae (Annelida). Zoologica Scripta. 2017; 46 (5); 596610. Available from: https://doi.org/10.1111/zsc.12238

7. Anctil M. The epithelial luminescent system of Chaetopterus variopedatus. Can J Zool. 1979; 57 (6): 1290-310. DOI: 10.1139/ Z79-166

8. Shimomura O, Johnson $\mathrm{FH}$, Haneda Y. Partial purification and properties of the Chaetopterus luminescence system. Bioluminescence in Progress. Princeton University Press; 1966 495521. Availablefrom:https://doi.org/10.1515/9781400875689031.

9. Branchini BR, Behney CE, Southworth TL, Rawat R, Deheyn DD. Chemical analysis of the luminous slime secreted by the marine worm Chaetopterus (Annelida, Polychaeta). Photochem Photobiol. 2014; 90 (1): 247-51. DOI: 10.1111/php.12169.

10. Shimomura O, Johnson FH. Chaetopterus photoprotein crystallization and cofactor requirements for bioluminescence. Science. 1968; 159 (3820): 1239-40. DOI: 10.1126/

\section{Литература}

1. Osborn KJ, Rouse GW, Goffredi SK, Robison BH. Description and relationships of Chaetopterus pugaporcinus, an unusual pelagic polychaete (Annelida, Chaetopteridae). Biol Bull. 2007; 212 (1): 40-54. DOI: 10.2307/25066579.

2. Petersen ME. Chaetopterus variopedatus (Renier) (Annelida: Polychaeta: Chaetopteridae): a species complex. What species are being used at MBL? Biol Bull. 1984; 167: 513. science.159.3820.1239.

11. Purtov KV, Petushkov VN, Rodionova NS, et al. Luciferin-luciferase system of marine polychaete Chaetopterus variopedatus. Dokl Biochem Biophys. 2019; 486 (1): 209-12. DOI: 10.1134/ S1607672919030104.

12. Shcheglov AS, Tsarkova AS. The potential of using the bioluminescent system of Chaetopterus variopedatus to study ferroptosis in living organisms. Bulletin of RSMU. 2021; (3): 7981. DOI: $10.24075 /$ vrgmu.2021.024

13. Dixon SJ, Lemberg KM, Lamprecht MR, Skouta R, Zaitsev EM, Gleason CE, et al. Ferroptosis: an iron-dependent form of nonapoptotic cell death. Cell. 2012; 149: 1060-72. DOI: 10.1016/j.cell.2012.03.042.

14. Li J, Cao F, Yin H-L, Huang Z-J, Lin Z-T, Mao N, et al. Ferroptosis: past, present and future. Cell Death Dis. 2020; 11 (2): 88. DOI: 10.1038/s41419-020-2298-2

15. Yan H-F, Zou T, Tuo Q-Z, Xu S, Li H, Belaidi AA, et al. Ferroptosis: mechanisms and links with diseases. Signal Transduct Target Ther. 2021; 6 (1): 49. DOl: 10.1038/s41392-020-00428-9.

16. Viviani VR, et al. Active-site properties of Phrixotrix railroad worm green and red bioluminescence-eliciting luciferases. J Biochem. 2006; 140 (4): 467-74. DOI: 10.1093/jb/mvj190.

17. Arnoldi FG, da Silva Neto AJ, Viviani VR. Molecular insights on the evolution of the lateral and head lantern luciferases and bioluminescence colors in mastinocerini railroad-worms (Coleoptera: Phengodidae). Photochem Photobiol Sci. 2010; 9 (1): 87-92. DOI: 10.1039/B9PP00078J.

18. Nakajim, Y, Ohmiya Y. Bioluminescence assays: multicolor luciferase assay, secreted luciferase assay and imaging luciferase assay. Expert Opin Drug Discov. 2010; 5 (9): 835-49. DOl: 10.1517/17460441.2010.506213

19. Syed AJ, Anderson JC. Applications of bioluminescence in biotechnology and beyond. Chem Soc Rev. 2021; 50: 5668-705. DOI: 10.1039/DOCS01492C

20. Slavine NV, McColl RW. Semi-automated Image processing for preclinical bioluminescent imaging. J Appl Bioinform Comput Biol. 2015; 4 (1): pii: 114. DOI: 10.4172/2329-9533.1000114.
3. Petersen ME. Contribution to a revision of Chaetopterus Cuvier (Polychaeta: Chaetopteridae): redescription of C. appendiculatus Grube and C. cautus Marenzeller, with comments on some other species. Bull Mar Sci. 1997; 60: 619.

4. Bhaud M. The spreading potential of polychaete larvae does not predict adult distributions; consequences for conditions of recruitment. Hydrobiologia. 1998; 375: 35. DOI: 
10.1023/A:1017073409259

5. Mirza JD, Migotto AE, Yampolsky IV, de Moraes GV, Tsarkova AS, Oliveira AG. Chaetopterus variopedatus bioluminescence: a review of light emission within a species complex. Photochem Photobiol. 2020; 96: 768-78. DOI: 10.1111/php.13221.

6. Moore JM, Nishi E, Rouse GW. Phylogenetic analyses of Chaetopteridae (Annelida). Zoologica Scripta. 2017; 46 (5); 596610. Available from: https://doi.org/10.1111/zsc.12238.

7. Anctil M. The epithelial luminescent system of Chaetopterus variopedatus. Can J Zool. 1979; 57 (6): 1290-310. DOI: 10.1139/ Z79-166.

8. Shimomura O, Johnson FH, Haneda Y. Partial purification and properties of the Chaetopterus luminescence system. Bioluminescence in Progress. Princeton University Press; 1966 495521. Availablefrom:https://doi.org/10.1515/9781400875689031.

9. Branchini BR, Behney CE, Southworth TL, Rawat R, Deheyn DD. Chemical analysis of the luminous slime secreted by the marine worm Chaetopterus (Annelida, Polychaeta). Photochem Photobiol. 2014; 90 (1): 247-51. DOI: 10.1111/php.12169.

10. Shimomura O, Johnson FH. Chaetopterus photoprotein: crystallization and cofactor requirements for bioluminescence. Science. 1968; 159 (3820): 1239-40. DOI: 10.1126/ science.159.3820.1239.

11. Purtov KV, Petushkov VN, Rodionova NS, et al. Luciferin-luciferase system of marine polychaete Chaetopterus variopedatus. Dokl Biochem Biophys. 2019; 486 (1): 209-12. DOI: 10.1134/ S1607672919030104.

12. Щеглов А. С., Царькова А. С. Перспективы использования биолюминесцентной системы Chaetopterus variopedatus для мониторинга ферроптоза в живых организмах. Вестник РГМУ. 2021; (3): 79-81. DOI: 10.24075/vrgmu.2021.024.

13. Dixon SJ, Lemberg KM, Lamprecht MR, Skouta R, Zaitsev EM, Gleason CE, et al. Ferroptosis: an iron-dependent form of nonapoptotic cell death. Cell. 2012; 149: 1060-72. DOI: 10.1016/j.cell.2012.03.042.

14. Li J, Cao F, Yin H-L, Huang Z-J, Lin Z-T, Mao N, et al. Ferroptosis: past, present and future. Cell Death Dis. 2020; 11 (2): 88. DOI: 10.1038/s41419-020-2298-2.

15. Yan H-F, Zou T, Tuo Q-Z, Xu S, Li H, Belaidi AA, et al. Ferroptosis: mechanisms and links with diseases. Signal Transduct Target Ther. 2021; 6 (1): 49. DOI: 10.1038/s41392-020-00428-9.

16. Viviani VR, et al. Active-site properties of Phrixotrix railroad worm green and red bioluminescence-eliciting luciferases. J Biochem. 2006; 140 (4): 467-74. DOI: 10.1093/jo/mvj190.

17. Arnoldi FG, da Silva Neto AJ, Viviani VR. Molecular insights on the evolution of the lateral and head lantern luciferases and bioluminescence colors in mastinocerini railroad-worms (Coleoptera: Phengodidae). Photochem Photobiol Sci. 2010; 9 (1): 87-92. DOI: 10.1039/B9PP00078J.

18. Nakajim, Y, Ohmiya $Y$. Bioluminescence assays: multicolor luciferase assay, secreted luciferase assay and imaging luciferase assay. Expert Opin Drug Discov. 2010; 5 (9): 835-49. DOI: 10.1517/17460441.2010.506213

19. Syed AJ, Anderson JC. Applications of bioluminescence in biotechnology and beyond. Chem Soc Rev. 2021; 50: 5668-705. DOI: 10.1039/DOCS01492C.

20. Slavine NV, McColl RW. Semi-automated Image processing for preclinical bioluminescent imaging. J Appl Bioinform Comput Biol. 2015; 4 (1): pii: 114. DOI: 10.4172/2329-9533.1000114. 